\title{
Editorial: Social change, civil society and the state...the struggle continues
}

\author{
Anthony Marcus $\cdot$ Kirk Dombrowski
}

Published online: 22 August 2009

(C) Springer Science+Business Media B.V. 2009

On 15, February 1989, when Soviet Premier Mikhael Gorbachev removed the last Red Army troops from Afghanistan, social movement leaders and political parties across the former colonial world began to realize that the era of Soviet support for their causes was over, and there was little strategic or financial advantage to be gained from navigating the space between the two rival state-superpowers. Although the Democratic Republic of Afghanistan (DRA) proved more resilient than anybody expected-inflicting a series of defeats on the mujahideen during its first 2 years of holding independent state power-most commentators at the time realized it was no match for "freedom fighters" being actively recruited, trained and resourced by the United States, Saudi Arabia, Pakistan, and Western Europeans as part of a planned final offensive against communism in Afghanistan. After the 1991 coup, when new Soviet Premier Boris Yeltsin joined the capitalist powers in their embargo of the DRA, the outcome of the Afghan Civil War of 1989-1992 became a foregone conclusion. The then weak and isolated Afghan government splintered into many pieces, and to those watching, the door seemed conclusively shutting on "liberationist" state building projects in the former colonial world. At that moment, a sense of historical impasse settled in on activists at the heart of the imperium, at least for "state centred" approaches.

Fidel Castro may have been the first leader in the third world to recognize the changed situation, as he struggled through the late 1980s against the declining Soviet support that accompanied Perestroika and Gorbachev's own harsh criticism of aggressive Cuban foreign policy. At the opposite end of the spectrum, Yasser Arafat was probably the last of these leaders to recognize the changed situation, making the unfortunate choice of siding with Baathist Iraq against the United States and its Al-Sabah clients in the Gulf War of 1990-1991. Indeed, by 1992, nearly everyone who had ever raised the flag of anti-capitalist or anti-colonial revolution

A. Marcus $(\varangle) \cdot$ K. Dombrowski

University of Melbourne, Melbourne, VIC, Australia

e-mail: amarcus@unimelb.edu.au 
with hopes of creating a Moscow alignment was either suing for peace, running for cover, looking for new (and typically illicit) sources of support for their movements, trying to build retirement funds late in life, or rebadging themselves as "democratic". Many of these leaders succeeded individually in coming in from the cold, thanks to the need in poor countries for their strong technical and political capacities; others, for whom there was no warm space, continued the fight, often in exile, with reduced circumstances, and under conditions of severe ideological disorientation.

For those grassroots activists who had never been close to state power-and who, perhaps, had never been comfortable with the compromises, political pretensions and brutal power-games connected to such nineteenth/twentieth century strategies of "taking power" - the changes that followed the fall of the Berlin Wall eased the horrible tensions of the Cold War and opened a period of new possibilities. The 1990s saw a remarkable efflorescence of democratic civil society/neo-communitarian projects, often in countries that had not previously had open political space. And these new political projects of culture, community, and local participation came to be viewed as far more compelling to progressives than the discredited and fading visions of communism, social democracy, third-worldism, and other statedominated views of change.

Not surprisingly, the first large-scale visible form of these new movements appeared where a state (that itself had once played on those same Cold War tensions) had abruptly changed course, and given up any pretence of its past socialist ambitions or an escape from US hegemony. On 1 January 1994, the EZLN or Zapatista Movement of Chiapas in southern Mexico electrified the progressive world with its clarion call to take up multiple, varied and different forms of struggle. Their indigenous perspective on direct grassroots action and proactive local civic participation resonated with this new generation of political activists, most of whom were already at work "thinking globally and acting locally." The ludic charm of Subcommandante Marcos, their most public representative, sparked solidarity, commentary, and imitation across the planet, while academics and activists like Jorge Casteñeda, Antonio Negri, and Michael Hardt looked for descriptions of and explanations for the political nature of the period. Finally, in Seattle in 1999, an anti-globalization movement that had already passed a decade experiencing, being schooled in, and broadening and deepening the techniques and histories of postCold War struggle, exploded onto the international mediascape with the famous N30 protests against the World Trade Organization meetings.

That was 10 years ago and in the intervening years those activists and millions more have come together in a variety of political and social affiliations and struggles over a variety of globally significant events that have marked the ever changing and still largely undefined zeitgeist of post-Cold War progressivism. As with the movements themselves, our editorial collective does not speak in one voice about the proposition (posed so clearly by the title of John Holloway's 2002 book Change the World Without Taking Power): that state power is no longer an immediate goal of progressive mobilization. However, we share a general consensus in believing that the visions that emerged from N30 currently stand as the most visible and popular programs for social transformation, and that they represent a critical step in 
what all have recognized as a fundamental reorganization in global political economy at the end of the twentieth century.

In the name of using this tenth anniversary of the "Battle in Seattle" as a useful point of reflection on where we have come since N30, Dialectical Anthropology presents a special issue guest edited by Avram Bornstein, which includes a group of scholars who have spent these last 10 years studying, thinking about, and participating in these movements. This special issue aims to provide both a rethinking of the events of $\mathrm{N} 30$ itself and some critical reflection on where direct action and other sorts of grass rooted movements are headed; and importantly, it also seeks to begin to track the reactions of global capitalism to this newest challenge. In a future issue, we hope to provide such a forum to progressives who, by virtue of their different political convictions and commitments, have been less engaged with and perhaps less sanguine about the value of this approach to social change, and who would like to see other forms of political ambition put back on the table. Taken together, we see this sort of dialogue as a crucial part of continuing the discussion about how to transform the outmoded capitalist system that continues to lurch from crisis to crisis, chewing up everybody in its path. 